\title{
Green spaces, excess weight and obesity in Spain
}

Cristina O'Callaghan-Gordo 1,2,3, Ana Espinosa 1,2,3,4, Antonia Valentin 1,2,3, Cathryn Tone $^{1,2,3}$, Beatriz Pérez-Gómez ${ }^{3,5}$, Gemma Castaño-Vinyals ${ }^{1,2,3,4}$, Trinidad DierssenSotos ${ }^{3,6}$, Conchi Moreno-Iribas 3,7,8, Silvia de Sanjose ${ }^{3,9}$, Guillermo Fernandez-Tardón 3,10, Mercedes Vanaclocha-Espi ${ }^{3,11}$, María Dolores Chirlaque ${ }^{3,12}$, Marta Cirach 1,2,3, Nuria Aragonés ${ }^{3,5}$, Inés Gómez-Acebo ${ }^{3,13}$, Eva Ardanaz ${ }^{3,7,8}$, Víctor Moreno ${ }^{3,9,14}$, Marina Pollan 3,5, Mariona Bustamante 1,2,3, Mark J. Nieuwenhuijsen 1,2,3, Manolis Kogevinas $1,2,3,4$

${ }^{1}$ ISGlobal, Barcelona, Spain; ${ }^{2}$ Universitat Pompeu Fabra (UPF), Barcelona, Spain; ${ }^{3}$ CIBER Epidemiología y Salud Pública (CIBERESP), Madrid, Spain; ${ }^{4}$ Municipal Institute of Medical Research (IMIM-Hospital del Mar), Barcelona, Spain; ${ }^{5}$ Cancer and Environmental Epidemiology Unit, National Center of Epidemiology, Carlos III Institute of Health, Madrid, Spain; ${ }^{6}$ Universidad de Cantabria - IDIVAL, Santander, Spain; ${ }^{7}$ Navarra Public Health Institute, Pamplona, Spain: ${ }^{8}$ IdiSNA, Navarra Institute for Health Research, Pamplona, Spain; ${ }^{9}$ Cancer Prevention and Control Program, Catalan Institute of Oncology-IDIBELL, L'Hospitalet de Llobregat, Spain; ${ }^{10}$ IUOPA, University of Oviedo, Spain; ${ }^{11}$ Cancer and Public Health Area, FISABIO - Public Health, Valencia, Spain; ${ }^{12}$ Department of Epidemiology, Regional Health Council, IMIB-Arrixaca, Murcia University, Murcia, Spain; ${ }^{13}$ Universidad de Cantabria - IDIVAL, Santander, Spain; ${ }^{14}$ Department of Clinical Sciences, Faculty of Medicine, University of Barcelona, Barcelona, Spain

\section{Corresponding author}

Cristina O'Callaghan-Gordo; email: cristina.ocallaghan@isglobal.org; postal address: Doctor Aiguader 88, 08003 Barcelona, Spain 


\begin{abstract}
Background. The epidemiological evidence on green spaces and obesity is inconsistent.

Objectives. To study the association of access to green spaces and surrounding greenness with obesity in Spain.

Methods. We enrolled 2354 individuals 20-85 years from urban areas of seven provinces of Spain between 2008-13. Subjects were randomly selected population controls of the MCC-Spain case-control study. We geocoded current residences and defined exposures in a buffer of $300 \mathrm{~m}$ around them: i) access to green space, identified using Urban Atlas, and ii) levels of surrounding greenness, measured by the Normalized Difference Vegetation Index. We examined excess weight/obesity as binary outcomes based on body mass index and waist-hip ratio. We examined effect modification by genetic factors, sex and individual socio-economic status and mediation by physical activity and concentrations of $\mathrm{PM}_{2.5}$ and $\mathrm{NO}_{2}$. To assess potential effect modification by genetic factors, we used a polygenic risk score based on obesity polymorphisms detected in genome-wide association studies. We used logistic mixed-effects models with a random effect for catchment area adjusted for potential confounders.
\end{abstract}

Results. Access to green space was associated with a reduced risk of excess weight/obesity after adjusting for confounders [excess weight: OR $(95 \% \mathrm{CI})=0.82(0.63$, 1.07), p-value $=0.143$; abdominal obesity: OR $(95 \% \mathrm{CI})=0.68 \quad(0.45,1.01)$, pvalue $=0.057]$. In the stratified analysis, this association was only observed in women. Associations between surrounding greenness and excess weight/obesity were null or modest based on a $1 \mathrm{IQR}$ increase in NDVI [excess weight: OR $(95 \% \mathrm{CI})=0.99(0.88$, 1.11), p-value $=0.875$; abdominal obesity: OR $(95 \% \mathrm{CI})=0.91 \quad(0.79,1.05), \quad \mathrm{p}$ value $=0.186]$. The observed associations were not mediated by physical activity or air pollution.

Discussion. Access to green space is associated with decreased risk of excess weight/obesity among women in Spain. Mechanisms explaining this association remain unclear.

\title{
Keywords
}

Green space; surrounding greenness; overweight; obesity; body mass index; waist-to-hip ratio 


\section{Introduction}

Prevalence of overweight and obesity has increased globally in the last decades. In 2013, it was estimated that there were 2.1 billion overweight and obese individuals worldwide ( $\mathrm{Ng}$ et al., 2014). High body weight is an important risk factor for several noncommunicable diseases, including cardiovascular, kidney and liver diseases, diabetes, musculoskeletal disorders and some cancers (Abdelaal et al., 2017; MacMahon et al., 2009; Wormser et al., 2011), and it has been also associated with increased risk of allcause mortality (Global BMI Mortality Collaboration, 2016). Several factors have been associated with obesity including: lifestyle (e.g. lack of physical activity, unhealthy eating patterns, not enough sleep, high amounts of stress), social and environmental factors (e.g. low socioeconomic status, unsafe environment in the neighbourhood, built environment factors, exposure to obesogenic chemicals), family history and genetics, race, and sex. These factors are related to changes in the prevalence of obesity either directly or, as in the case of genetic factors, by interacting with modifiable (environmental) exposures.

Natural outdoor environments, including green spaces within urban settings can promote health and wellbeing by increasing levels of physical activity (e.g. leisure-time physical activity and active transportation), reducing exposure to noise, reducing exposure to air pollution, and promoting psychological stress reduction and restoration, among other mechanisms (Hartig et al., 2014; Markevych et al., 2017; Nieuwenhuijsen et al., 2017). Physical inactivity and physiological stress are important drivers of weight gain (Harding et al., 2014). A recent review concluded that chronic exposure to noise is associated with increased waist circumference (An et al., 2018), and there is some evidence that air pollution may also be associated with obesity (Jerrett et al., 2014). A systematic review of the existing studies on green spaces and obesity conducted in 2010 (Lachowycz and Jones, 2011), concluded that although most of the studies reported some association between green spaces and lower body mass index (BMI), this association was in some cases only present in relation to certain types of green spaces or among certain populations. A recent study conducted in Spain reported that people living in neighbourhoods without green space were more likely to have higher BMI and to be obese compared to people living in neighbourhoods that had green space (Raftopoulou, 2017).

Genetic factors have been also associated with obesity. Large genome-wide association studies (GWAS) conducted in around 400.000 individuals have identified more than 100 single-nucleotide polymorphisms (SNPs) associated with BMI implicating several biological pathways (Locke et al., 2015; Speliotes et al., 2010). Polygenic risk scores evaluating the cumulative effect of obesity polymorphisms have shown a positive association with body weight. These genetic effects may be enhanced in persons with high BMI underscoring the importance of gene-gene and gene-environment (GxE) interactions (Abadi et al., 2017). The role, however, of gene-environment interactions in determining BMI has been poorly evaluated (Rask-Andersen et al., 2017).

In the current study we investigated the association between residential access to green spaces and surrounding greenness and obesity using two different markers of excess weight and obesity: BMI and waist-to-hip ratio (WHR) in large urban areas of Spain. We also the investigated if physical activity and/or air pollution mediated the association between green spaces and obesity and if genetic factors modified the effect.

\section{Methods}




\section{Study population.}

We used data on randomly selected population controls from the multi-case control study in Spain (MCC-Spain study) living in urban areas with more than 100.000 inhabitants to conduct a cross-sectional analysis. The MCC-Spain study is a population based multicase control study on frequent tumours in Spain. The methodology has been described elsewhere (Castaño-Vinyals et al., 2015). Briefly, between 2008-2013, histologically confirmed incident cases of colorectal, breast, prostate, stomach and chronic lymphocytic leukaemia were recruited in 23 hospitals from 12 provinces of Spain. Controls were randomly selected from the administrative records of selected primary care health centres located within these hospitals' catchment area and were contacted telephonically to offer participation. Participants were 20-85 years' old who had been living in the catchment area at least 6 months prior to study enrolment. We excluded the following participants (supplemental material, figure S1): i) those whose current address could not be geocoded, ii) those currently living in areas rural areas or urban areas with less than 100.000 inhabitants (areas not covered by the Urban Atlas (European Environment Agency, 2006), iii) those with missing information on BMI and/or with missing information on waist and hip measurements and iv) those with missing information on basic co-variables.

The study was approved by the Ethics Committee of all participating hospitals and primary health care centres and it followed the national and international directives on ethics and data protection [declaration of Helsinki and Spanish law on confidentiality of data (Ley Organica 15/1999 de 13 Diciembre de Proteccion de Datos de caracter personalLOPD)]. All subjects provided written informed consent prior to participation in the study.

\section{Data collection.}

Participants were interviewed by study personnel and information on the following characteristics was recorded in a structured questionnaire (http://www.mccspain.org/): i) residential history, which included full address and number of years lived in each residence where the participant had lived for at least one year, from the $18^{\text {th }}$ years of age to interview date; ii) socio-demographic factors; iii) lifestyle factors, including information on leisure time physical activity during the last 10 years (excluding the 2 years before study recruitment); and iv) self-reported weight and height at time of the interview and one year earlier. After the interview, hip and waist circumference was measured by trained study personnel. When possible, peripheral blood was drawn from participants. For those participants who refused to give blood, saliva was collected using the Oragene® DNA Kit.

\section{Indicators of excess weight and obesity.}

We used two indicators of overweight/obesity based on different markers commonly used in epidemiological studies: BMI and WHR. BMI is the most widespread criterion used to classify excess weight and obesity, as a surrogate of body fat composition. WHR is a measure of body fat distribution, often used as a surrogate of abdominal fat. Different studies have found that WHR is a better predictor or obesity-related morbidity than BMI, in both men and women (World Health Organization, 2008. Waist Circumference and Waist-Hip Ratio: Report of a WHO Expert Consultation). We defined "excess weight" if 
BMI was $\geq 25 \mathrm{~kg} / \mathrm{m}^{2}$, and "abdominal obesity" if WHR was $\geq 0.85$ for women and $\geq$ 0.90 for men, according to the WHO stablished categories ((World Health Organization, 2008, 1995).

\section{Residence based covariates.}

As previously described (O'Callaghan-Gordo et al., 2018), current residence address (i.e. residence at time of study enrolment of each study participant) was geocoded using geographic information systems (GIS; Geospatial Modelling Environment (Version 0.7.3.0) and ESRI ® ArcMap TM 10.0, ArcGIS Desktop 10 Service Pack 4). Levels of air pollution, and of socio-economic level were assigned to each residence. We calculated the exposure to levels of outdoor air pollution for each address using the European land use regression model developed by Wang et al (Wang et al., 2014), which is based on the ESCAPE project models for $\mathrm{PM}_{2.5}$ (Eeftens et al., 2012) and $\mathrm{NO}_{2}$ (Beelen et al., 2013). We assigned indicators of socio-economic status in the area of residence based on the Urban Vulnerability Synthetic Index of Socioeconomic Criteria (ISVU-SE) created by Spanish Department of Architecture, Housing and Land Development (Ministry of Public Works (Spain), 2001) and we generated quintiles of ISVU-SE (population in the highest quintile was population from the most vulnerable areas, population from the lowest quintile was population from the least vulnerable areas).

\section{Exposure to green spaces}

We calculated two indicators of exposure to green spaces for each study participant: presence of green space and surrounding greenness, within $300 \mathrm{~m}$ from the current residence, based on the distance recommended by the European Commission for selection of indicators of urban green space in health studies (WHO Regional Office for Europe, 2016).

The selection of these two exposures encompassed differences of green spaces: i) presence of green spaces is a surrogate for access to these spaces (for simplification we will refer to "access to green space" through the manuscripts when referring to presence of green spaces), and ii) residential surrounding greenness is an indicator of general outdoor greenness of the participants' neighbourhoods.

We defined access to green space as a binary indicator representing the presence of "public green areas for predominantly recreational use such as gardens, zoos, parks of at least $0.25 \mathrm{Ha}$ " and/or "forest" (i.e. "forests with ground coverage of tree canopy $>30 \%$, tree height $>5 \mathrm{~m}$, including bushes and shrubs at the fringe of the forest" of at least $1 \mathrm{Ha}$ ) according to Urban Atlas categories of land use and land cover (European Environment Agency, 2006). We defined surrounding greenness as the amount of photosyntheticallyactive greenness using the Normalized Difference Vegetation Index (NDVI). NDVI is derived from the Landsat 7 (http://landsat.usgs.gov/) images at a resolution of 30x30 meters. NDVI is an index ranging -1 to 1 where higher positive values indicate more greenness (Weier and Herring, 2000). Negative values of NDVI mainly correspond to water bodies. We excluded large water bodies from the NDVI satellite imagery before data analysis (PHENOTYPE study protocols (http://www.phenotype.eu/en/), so negative values did not affect the final greenness averages. We looked for available cloud-free Landsat TM for the years 2000-2001 images during springs (i.e., the maximum vegetation 
period for the study region) from the NASA's Earth Observing System Data and Information System (EOSDIS) website (https://earthdata.nasa.gov/).

\section{Genotyping and generation of polygenic risk score.}

A subsample of participants included in this analysis $(n=1853)$ had information on genotype. $96 \%$ of participants from the MCC-Spain study provided blood or saliva samples. A random selection of $70 \%$ of the samples that were from European ancestry origin, had complete epidemiological information, and good DNA quality were genotyped. Genome-wide genotyping was performed using a tailored version of the Infinium Human Exome BeadChip Kit v.1.1 (Illumina) that allowed the inclusion of approximately 6000 customized SNPs (selected based on pathways of interest for MCCSpain study). The genotype calling was done with the GeneTrain2.0 algorithm (GenomeStudio software) based on CHARGE clusters (Grove et al., 2013). PLINK was used for the genetic data quality control (Purcell et al., 2007), and the standard checks were done: sample call rate, sex concordance, heterozygosity, relatedness, population stratification, SNP call rate and departure from Hardy-Weinberg equilibrium (HWE) for each SNP.

We created a weighted polygenic risk score by adding the weighted risk alleles of 30 out of the 32 BMI SNPs previously described to be robustly associated with BMI (Speliotes et al., 2010). Twenty-eight of these SNPs were genotyped in the MCC-Spain study. For two of the genes not genotyped in the MCC-Spain study, we found proxy SNPs (r2>0.66) while for the other two we could not find a proxy. To validate the applicability of these score to our study population, we estimated the effect of these 30 SNPs as well as the effect of the polygenic risk score in relation to BMI using linear regression models (supplemental material, figure S2).

\section{Statistical analysis.}

We conducted descriptive analyses of the study population. We used generalized additive models (GAMs) to examine the shape of the dose-response relationship between surrounding greenness and the different outcomes under study (supplemental material, figure S3). To study the association between access to green spaces and surrounding greenness and the two binary indicators of excess weight/obesity (i.e. excess weight and abdominal obesity) we used logistic mixed-effects models. Additionally, to explore the association between access to green spaces and surrounding greenness with BMI and WHR as a continuous variable we used mixed-effects linear regression models.

All models included a random effect for catchment area. For surrounding greenness, we reported the results for 1 interquartile range (IQR) increase in average NDVI (at $300 \mathrm{~m}$ ) based on all study population. We used Directed Acyclic Graphs (DAGs) to summarize the information on potential confounders and mediators, and identify which of them should be included in the final model (supplemental material, figure S4).

We ran basic models adjusted for age and sex, and models further adjusted for all other identified confounders: age, sex, education (i.e. primary or lower, or secondary or higher), individual socioeconomic status (i.e. score based on parents' economical level, own education and occupational category), and area level socioeconomic status (i.e. urban vulnerability index (Ministry of Public Works (Spain), 2001)). We checked collinearity 
assessing the variance inflation factor in the fully adjusted model (adjusted for all potential confounders) (Greenland et al., 2016).

We conducted mediation analyses to test the hypothesis about the two pathways through which green spaces could have an effect on excess weight/ obesity: direct effect or indirect effect through a mediator variable (Hayes, 2009). We estimated the indirect effect of the following potential mediator variables: physical activity [i.e. low levels $(\leq 8$ metabolic equivalent of tasks (METs) hour/week) or high levels (> 8 METs hour/week)], nitrogen dioxide $\left(\mathrm{NO}_{2}\right)$ and particulate matter less than $2.5 \mu \mathrm{m}\left(\mathrm{PM}_{2.5}\right)$ using methods for causal mediation analysis previously described by T. J. VanderWeele and S. Vansteelandt (VanderWeele and Vansteelandt, 2010). We calculated direct and indirect effects using a regression-based approach under the following assumptions: (i) no unmeasured exposureoutcome confounding, (ii) no unmeasured mediator-outcome confounding, (iii) no unmeasured exposure-mediator confounding, (iv) no effect of exposure that confounds the mediator-outcome relationship, and (v) not interaction between the mediator variables and the exposure variables.

We explored effect modification by sex, socio-economic status using likelihood ratio test (LRT). Among participants with the pertinent data $(n=1853)$, we also explored effect modification by polygenic risk score using a cut-off value of the score $\leq 75 \%$. Alternative cut-off values were also considered (above and below the median, and $>75 \%$ value versus $<25 \%$ value). We examined gene-environment interactions testing simultaneously the main effect for the polygenic risk score and the interaction term with the exposure using the LRT (Kraft et al., 2007)). The joint test considers the hypothesis that the polygenic risk score is associated with risk of disease in both exposure groups. Given the low power of LRT to test for interactions (Rothman, Kenneth J.; Greenland, Sander; Lash, 2008), we considered a significance $\mathrm{p}$-value $<0.2$. In agreement with previous literature, a $\mathrm{p}$ value $<0.05$ was set as the as significance value for all other tests. However, despite reporting p-values, we did not base the interpretation and discussion of the associations under the study based on p-values (Amrhein et al., 2019).Statistical analyses were conducted using Stata version 14 (StataCorp, College Station, TX, USA).

\section{Results}

\section{Study population}

Overall 2354 participants fulfilled the study criteria of the current analysis and had information on access to green spaces. Data on surrounding greenness (i.e. data from Landsat 7 images) was available for 2352 participants from seven different provinces of Spain (supplemental material, figure S5), as this information was not accessible for participants who lived in remote areas ( $\mathrm{n}=2,<0.01 \%$ of study participants). Mean (SD) surrounding greenness was higher among study participants with access to green spaces [0.23 (0.09) versus 0.18 (0.08), p-value<0.001]. Eighty-two per cent $(1936 / 2354)$ of participants had been living in the current residence at least 10 years before study enrolment; for $72 \%(1707 / 2354)$ of study participants, the current residence was also the longest residence where they have lived. Overall, the mean (SD) length of residence in current residence was 25 (14) years. Mean (SD) BMI of study participants was 26.6 (4.2) $\mathrm{kg} / \mathrm{m}^{2}$ [27.3 (3.6) in men, 25.8 (4.8) in women], and mean (SD) WHR of study participants was $0.91(0.10)$ [0.85 (0.09) in men, $0.97(0.07)$ in women]. These variables were moderately correlated (Spearman's correlation coefficient $=0.47$, p-value $<0.001$ ). 
Sixty-two per cent of participants had BMI $\geq 25 \mathrm{Kg} / \mathrm{m}^{2}: 43 \%$ had BMI $25-30 \mathrm{Kg} / \mathrm{m}^{2}[58.8$ of men, 32.4 of women], and $19 \%$ had BMI $\geq 30 \mathrm{Kg} / \mathrm{m}^{2}$ [22.1 of men, 17.4 of women]. Sixty-eight per cent of study participants were obese according to WHR definition (referred in the study as abdominal obesity).

Table 1 shows characteristics of participants according to excess weight, and abdominal obesity. In summary, overweight/obese individuals (according to the two different definitions of excess weight /obesity used in the study) were older, more likely to be male, less physically active, had lower levels of education and socioeconomic status, and were more likely to live in the most vulnerable areas compared to non-obese individuals. Characteristics of participants according to presence of green spaces around the residence are presented in supplemental material, table S1. Briefly, individuals with no access to green space within $300 \mathrm{~m}$ of their residence had higher WHR and were older than those with access to green space. There was a higher proportion of participants from less vulnerable areas (lowest vulnerability index) among those with no access to green space within $300 \mathrm{~m}$ of their residence.

\section{Access to green space and excess weight/obesity}

Eighty-five per cent (2003/2354) of the study population had access to green space (i.e. urban green areas and/or forests according to Urban Atlas categories) within $300 \mathrm{~m}$ of their residence. The proportion of participants with access of green spaces was lower among people with abdominal obesity compared to non-obese people (p-value $<0.001$ for abdominal obesity, table 1).

Participants with access to green space within $300 \mathrm{~m}$ of their residence had lower risk of excess weight/obesity [excess weight: adjusted OR $(95 \mathrm{CI} \%)=0.82(0.63,1.07)$, pvalue $=0.143$; abdominal obesity: adjusted $\mathrm{OR}(95 \mathrm{CI} \%)=0.68(0.45,1.01)$, $\mathrm{p}$ value $=0.057$ ] compared to those without access. Results were consistent for the two indicators of excess weight/obesity used (table 2). When BMI and WHR were treated as continuous variables, we did not observe an association with access to green space [BMI: adjusted $\beta$ coefficient $(95 \% \mathrm{CI})=-0.32(-0.81,0.17)$, $\mathrm{p}$-value $=0.206]$; WHR: adjusted $\beta$ coefficient $(95 \% \mathrm{CI})=-0.002(-0.012,0.008)$, $\mathrm{p}$-value $=0.705]$.

Results of the sensitivity analysis including only participants who had lived in the current residence for at least 10 years $(n=1934)$ were very similar to results obtained in the overall population [excess weight: adjusted OR $(95 \mathrm{CI} \%)=0.76(0.57,1.02), \mathrm{p}$-value $=$ 0.067 ; abdominal obesity: adjusted OR $(95 \mathrm{CI} \%)=0.64(0.39,1.03), \mathrm{p}$-value $=0.065]$.

We observed an interaction between sex and access to green space and abdominal obesity ( $\mathrm{p}$-value for interaction $=0.056)$. The association between access to green spaces and reduced risk of abdominal obesity was only observed in women (table 2). We did not observe an interaction between socio-economic status and access to green space and excess weight/obesity (excess weight: $\mathrm{p}$-value for interaction $=0.636$, abdominal obesity: $=0.409$ ).

There was no evidence for interaction between the polygenic risk score and access to green spaces and excess weight/obesity (p-values for interaction $>0.2$ for all definitions excess weight/obesity). Still, we explored the strata specific associations. We observed a more marked reduction in risk of excess weight/obesity among those with access to green 
space within $300 \mathrm{~m}$ of the residence and with obesity polygenic risk score values $>75 \%$ compared with those with lower values (table 3). Similar results were observed when other cut-off the values were considered to compare high and low values of the obesity polygenic risk score (supplemental material, table S2).

As shown on table 4, the (total) effect exerted by access to green spaces on weight/obesity was explained by a direct effect as the total effect observed was almost the same as the direct effect, and no indirect effect was explained by any of the mediators considered (OR close to null value).

\section{Surrounding greenness and excess weight/obesity}

Mean (SD) level of surrounding greenness in the study population was 0.22 (0.09). Mean (SD) levels of surrounding greenness around home residence were slightly lower for excess weight/obese people compared to normal weight people ( $\mathrm{p}$-value $<0.001$ for both definitions of excess weight/obesity used, table 1). Median (IQR) level of surrounding greenness in the study population was 0.20 (0.09). Median (IQR) levels of surrounding greenness around home residence were also slightly lower for excess weight people compared to normal weight people [0.20 (0.08) versus $0.21(0.11)$, Wilcoxon rank-sum $\mathrm{p}$-value $=0.002]$, and for people with abdominal obesity compared to people without abdominal obesity [0.19 (0.08) versus $0.22(0.12)$, Wilcoxon rank-sum p-value < 0.001$]$.

No association was observed between levels of surrounding greenness within $300 \mathrm{~m}$ of the residence and excess weight [adjusted OR $(95 \mathrm{CI} \%)=0.99(0.88,1.11)$, pvalue $=0.875$ ), table 5]; however, there was some evidence or reduced abdominal obesity among those living in areas with higher levels of surrounding greenness [adjusted OR $(95 \mathrm{CI} \%)=0.91(0.79-1.05), \mathrm{p}$-value $=0.186$, table 5]. When BMI and WHR were treated as continuous variables, there was some evidence of reduced BMI among participants with higher levels of surrounding greenness within $300 \mathrm{~m}$ of the residence [adjusted $\beta$ coefficient $(95 \% \mathrm{CI})=-0.18(-0.38-0.01)$, p-value $=0.071]$, but no association was observed between surrounding greenness and WHR [adjusted $\beta$ coefficient $(95 \% \mathrm{CI})=-$ $0.002(-0.007,0.002)$, p-value $=0.347] . "$

Results of the sensitivity analysis including only participants who had lived in the current residence for at least 10 years $(n=1934)$ were also similar to results obtained in the overall population [excess weight: adjusted OR $(95 \mathrm{CI} \%)=0.98(0.86,1.12), \mathrm{p}$-value $=0.775$ ] abdominal obesity: adjusted OR $(95 \mathrm{CI} \%)=0.91(0.75,1.10), \mathrm{p}$-value $=0.340]$.

There was evidence for interaction with sex in the association between surrounding greenness and excess weight/obesity (excess weight: $\mathrm{p}$-value for interaction $=0.056$; abdominal obesity: $\mathrm{p}$-value for interaction $=0.021$ ). The association between surrounding greenness and reduced risk of excess weight/obesity was only observed in women, whereas in men there was some evidence of increased risk of excess weight/obesity among those living in areas with higher levels of surrounding greenness (table 5). There was no evidence for interaction with socio-economic status (excess weight: p-value for interaction $=0.961$, abdominal obesity: $\mathrm{p}$-value for interaction $=0.232$ ).

The evidence for interaction between the polygenic risk score and surrounding greenness and excess weight/obesity was limited ( $\mathrm{p}$-values for interaction $>0.2$ for all definitions of excess weight/obesity). Nevertheless, we explored the strata specific associations. We 
observed a more marked reduction in risk of excess weight/obesity among those higher levels of surrounding greenness within $300 \mathrm{~m}$ of the residence and with obesity polygenic risk score values $>75 \%$ compared with those with lower score values (table 6). Similar results were observer when other cut-off values were considered (supplemental material, table S3).

As shown on table 7, the (total) effect exerted by surrounding greenness on weight/obesity was explained by a direct effect as the total effect observed was almost the same as the direct effect, and no indirect effect was explained by any of the mediators considered (OR close to null value).

\section{Discussion}

In this study we investigated the association between access to green spaces and surrounding greenness, excess weight and obesity in large urban areas of Spain. We observed a reduction in risk of excess weight and obesity among participants who had access to a green area within $300 \mathrm{~m}$ of their current residence. These associations were less marked for surrounding greenness. We did not identify physical activity or air pollution as mediators explaining these associations. Finally, we observed that the association between green spaces and reduced risk of excess weight/obesity was only observed in women. In the analysis stratified by genetic score, we observed a more marked association between access to green spaces and surrounding greenness and excess weight/obesity, among subjects carrying multiple obesity risk alleles. However, the interaction between access to green urban areas and surrounding greenness, and genetic score was not statistically significant.

In general, previous studies suggest some association between access to green spaces and surrounding greenness and reduction in risk of obesity (reviewed by (Lachowycz and Jones, 2011)). However, results of studies focusing on the adult population do not show consistent results across population or demographic groups. A study conducted in 8 European cities, reported that higher levels of greenery were associated with lower odds of obesity (Ellaway et al., 2005). A study conducted in United States of America, showed association between access to parks and lower BMI among white Americans, but not among African Americans (Scott et al., 2009). In a study conducted in New Zealand, no association was observed between access to parks and BMI (Witten et al., 2008). Differences in the above mentioned studies can be explained by differences in the definition of "green spaces" used in each study (i.e. objective assessment of greenery conducted by the study personnel, number of parks or percentage of green space at a given distance of home address and/or distance to parks from home address). However, the cultural context can be an important modifier of the association between green spaces and health outcomes (Nieuwenhuijsen et al., 2017), and therefore, different results among different population could be found even if exposure to green spaces was estimated in the same way.

The association between green spaces and reduced risk of excess weight/obesity was only observed in women, whereas there was some evidence of increased risk of excess weight/obesity among men living in areas with higher levels of surrounding greenness. Similar results have been reported in a study from Australia, where an association was detected between access to parks and lower BMI in women, but not in men (Astell-Burt et al., 2014). Both biological and social determinants of obesity vary widely by gender 
(Kanter and Caballero, 2012). It is not clear which biological determinants could explain the differences in obesity patterns by gender observed in this study, but social determinants could explain them. For instance, the effect of socio-economic status in obesity differs by gender. Several studies conducted in western countries (including Spain), indicate that lower socio-economic status is a risk factor for obesity in general, but specially for women (Devaux and Sassi, 2013; Merino Ventosa and Urbanos-Garrido, 2016; Roskam et al., 2010). Although in the current study we controlled for socioeconomic status using several variables, residual confounding could still be present, and could explain in part the association observed between green spaces and obesity among women. Also, as commented in the previous paragraph, the benefit of green spaces seems to vary depending on the populations and groups studied, suggesting that perceptions and use of green spaces are important aspects to consider in epidemiological studies on green spaces. In concordance to this, a study from United Kingdom, reported differences by gender association between green spaces and different health outcomes and the authors attributes gender differences to different usage of green areas between men and women (Richardson and Mitchell, 2010).

Some previous studies have reported that physical activity partially mediates the effect between green spaces and different health outcomes, including obesity (Dadvand et al., 2016; James et al., 2016; Richardson et al., 2013). However, a recent review on this topic including 50 studies indicates that results from different studies are not consistent (Lachowycz and Jones, 2011). As explained above, discrepancies in results from different studies can be explained by heterogeneity in the definitions of exposure to green spaces and cultural context. Moreover, not all green spaces are equally attractive for physical activity, and other features of the built environment, such as perceived safety or access to facilities might affect the use of green spaces (Humpel et al., 2002; Lee and Maheswaran, 2011) and therefore affect the association between residential proximity to green spaces and obesity. We did not observe mediation effect by physical activity in our results. However, two limitations of the current study might have affected the results of the mediation analysis by physical activity: First, physical activity recorded in the MCCSpain study corresponded only to leisure time physical activity and it did not include physical activity related to active transportation, which can be also related to proximity to green spaces (Hartig et al., 2014). Second, in the MCC-Spain study, similar to most other studies, information on physical activity was self-reported and therefore susceptible to misclassification. In our study, misclassification (if any) is very likely to have been non-differential, given the initial aims of the MCC-Spain study, the structure of the interview used to record information and the objective classification of exposure to green spaces based on geocoded addresses.

Previous data on potential association between air pollution and obesity is not conclusive. (Fioravanti et al., 2018; Jerrett et al., 2014). We did not find a consistent association between air pollution and obesity. Apart from air pollution and physical activity, other mechanisms could explain the association observed between access to green spaces and reduction in risk of obesity (Frumkin et al., 2017). Green spaces have been associated with psychological stress reduction (van den Berg et al., 2010; Ward Thompson et al., 2016), and psychological stress has been associated with weight gain and obesity (Ayanian et al., 2009; Dallman et al., 2003). We could not explore these potential pathways as information on psychological stress was not available in the MCC-Spain study. Information on other potential mediators explaining the association observed 
between green spaces and obesity including food environment, walkability and noise around the residence were not available in the current study.

We found that the association between access to green spaces and risk of excess weight/obesity seemed to be more marked among people with the highest genetic predisposition to obesity although statistical tests for interaction were not significant. This overall tendency was observed irrespective of boundaries in either the definition of the polygenic risk scores or the green space classifications although to some extent results varied depending on the cut-offs and exposures examined. The effect of genetic factors on obesity has been shown to vary by BMI and to be more important among subjects with higher BMIs indicating a potential gene-gene or gene-environment interaction. Similarly, limited evidence in humans examining gene-environment interactions has shown that lifestyle and environmental factors such as alcoholism, physical activity and socioeconomic status can modify the effect of genetic predisposition to obesity (RaskAndersen et al., 2017). The potential interaction examined in our study should be further explored in larger studies with higher statistical power.

BMI was calculated from self-reported height and weight. Previous studies have shown that although self-reported BMI tends to underestimate real BMI, the correlation between them is high (Kuczmarski et al., 2001; McAdams et al., 2007). This limitation is overcome by the inclusion of WHR, which is based on objective measures. The potential nondifferential miss-classification in BMI could explain why the associations with excess weight (based on BMI) are less clear than the associations observed with abdominal obesity (based on WHR).

We explored the association between green spaces around the current residence and obesity. The current exposures considered in the study reflect long term exposures for the following reasons. First, in the study population the current residence was the same as the longest residence in $70 \%$ of study participants, and more than $80 \%$ of participants had been living in the current residence for at least 10 years. Second, measures of access to green spaces and surrounding greenness are stable over time. Land use data is considered very stable in time because few changes are made at high scale between versions (http://land.copernicus.eu/local/urban-atlas/change-2006-2009/view). Correlations made for NDVI in different years and seasons in one of the main areas included in the current study, showed Spearman's correlation coefficients values around 0.8 (Dadvand et al., 2012). Nevertheless, a recent study conducted in the Netherlands (Helbich, 2019) concluded that studies should aim at having NDVI data that matches temporally the epidemiological data as although annual NDVI levels tend to correlate the magnitude of the correlation can vary.

The association observed between green spaces and excess weight/obesity could be similar in other natural outdoor environments, for example blue spaces such as waterfront parks or marinas. We focussed our study in green spaces given the limited number of study participants exposed to blue spaces $(n=67,2.8 \%)$."

Our study has several strengths: First, we used two different indicators of excess weight and obesity. Most studies on green spaces and obesity have used BMI as the only marker of obesity. BMI is the most widespread criterion used to classify obesity, as a surrogate of body fat composition, but it has important limitations (Rothman, 2008). Therefore, it is valuable to include other indicators when studying obesity. We also used WHR, a 
measure of body fat distribution which is often used as a surrogate of abdominal fat (World Health Organization, 2008). WHR has been suggested as a better marker of obesity, especially among elder adults (Visscher et al., 2001). Second, the study included more than 2300 individuals, which ensured sufficient power to detect differences between groups, and allowed exploration of interactions with sex and socio-economic status. However, information on the polygenic risk score was only available for $70 \%$ of the study participants $(n=1653)$ and this has affected the power of the study to detect a potential interaction with the polygenic risk score. Third, we included urban populations from seven provinces of Spain enrolled through primary health care centres of the public health system, making our results generalizable to the Spanish population living in large urban areas. However, results from this study are not generalizable to small cities or rural areas, as such areas were not included in the study. The mean BMI of the study population was similar to the mean BMI among adult population in Spain (25-64 age groups). However, the prevalence of $\mathrm{BMI} \geq 25$ was higher in the study population, especially among men (Aranceta-Bartrina et al., 2016). These minor differences might be explained by the older age of the study population. Fourth, we had information on several covariables, including very detailed information on socio-economic status. This allowed us to adjust the models for education, socio-economic score based on parents and own income, education and occupation, and socio-economic score at area level. Finally, to our knowledge, this is the first study evaluating the modifying role of genetic susceptibility.

\section{Conclusion}

According to results from this study, access to green spaces may be associated with decreased risk of excess weight and obesity among women in Spain. Understanding the mechanisms that explain this association is crucial to plan effective and successful public health interventions. 
Table 1. Characteristics of the study participants according to excess-weight and abdominal obesity.

\begin{tabular}{|c|c|c|c|c|c|c|}
\hline \multirow[b]{2}{*}{ Characteristic $(\mathrm{n}=2354)$} & \multicolumn{3}{|l|}{$\begin{array}{l}\text { Excess } \\
\text { weight }\end{array}$} & \multicolumn{3}{|l|}{$\begin{array}{l}\text { Abdominal } \\
\text { obesity }\end{array}$} \\
\hline & $\begin{array}{l}\text { No, } \quad \mathrm{N}(\%) \\
\mathrm{N}=899\end{array}$ & $\begin{array}{l}\text { Yes, } \mathrm{N}(\%) \\
\mathrm{N}=1455\end{array}$ & p-value * & $\begin{array}{l}\text { No, } N(\%) \\
\mathrm{N}=756\end{array}$ & $\begin{array}{l}\text { Yes, } \mathrm{N}(\%) \\
\mathrm{N}=1598\end{array}$ & p-value * \\
\hline $\begin{array}{l}\text { BMI at study enrolment } \\
\left(\mathrm{kg} / \mathrm{m}^{2}\right) ; \text { mean }(\mathrm{SD})\end{array}$ & $22.6(1.8)$ & $29(3.4)$ & $<0.001$ & $24.3(3.8)$ & $27.7(4.0)$ & $<0.001$ \\
\hline $\begin{array}{l}\text { WHR at study enrolment; } \\
\text { mean (SD) } \\
\text { Access to green space }\end{array}$ & $0.9(0.1)$ & $0.9(0.1)$ & $<0.001$ & $0.8(0.1)$ & $1.0(0.1)$ & $<0.001$ \\
\hline No & $120(13.3)$ & $231(15.8)$ & & $63(8.3)$ & $288(18.0)$ & \\
\hline Yes & 779 (86.6) & $1224(84.1)$ & 0.094 & $693(91.7)$ & $1310(82.0)$ & $<0.001$ \\
\hline $\begin{array}{l}\text { Surrounding greenness } \\
\text { (NDVI); mean (SD); } \\
\mathrm{n}=2352\end{array}$ & $0.23(0.08)$ & $0.22(0.08)$ & 0.003 & $0.24(0.09)$ & $0.21(0.08)$ & $<0.001$ \\
\hline Age (years) ); mean (SD) & $59.2(13.2)$ & $64.3(10.5)$ & $<0.001$ & $56(13.1)$ & $65.4(10)$ & $<0.001$ \\
\hline \multicolumn{7}{|l|}{ Sex } \\
\hline Male & $331(36.8)$ & $892(61.3)$ & & $159(21.0)$ & $1064(66.6)$ & \\
\hline Female & $568(63.2)$ & $563(38.7)$ & $<0.001$ & $597(79.0)$ & $534(33.4)$ & $<0.001$ \\
\hline \multicolumn{7}{|l|}{ Physical activity } \\
\hline$\leq 8 \mathrm{METs}$ h/week & $460(51.2)$ & $812(55.8)$ & & $406(53.7)$ & $866(54.2)$ & \\
\hline$>8$ METs h/week & $439(48.8)$ & $643(44.2)$ & 0.028 & $350(46.3)$ & $732(45.8)$ & 0.824 \\
\hline \multicolumn{7}{|l|}{ Education } \\
\hline Primary or lower & $308(34.3)$ & $744(51.1)$ & & $269(35.6)$ & $783(49.0)$ & \\
\hline Secondary or higher & $591(65.7)$ & $711(48.9)$ & $<0.001$ & 487 (64.4) & $815(51.0)$ & $<0.001$ \\
\hline \multicolumn{7}{|l|}{ Socio-economic status } \\
\hline High & $239(26.6)$ & $198(13.6)$ & & $179(23.7)$ & $258(16.1)$ & \\
\hline Low & $191(21.2)$ & $510(35.1)$ & & $160(21.2)$ & $541(33.9)$ & \\
\hline Middle & $469(52.2)$ & $747(51.3)$ & $<0.001$ & 417 (55.2) & $799(50)$ & $<0.001$ \\
\hline \multicolumn{7}{|l|}{$\begin{array}{l}\text { Urban vulnerability index } \\
\text { (quintiles) }\end{array}$} \\
\hline 1 (least vulnerable) & $264(29.4)$ & $312(21.4)$ & & $232(30.7)$ & $344(21.5)$ & \\
\hline 2 & $213(23.7)$ & $346(23.8)$ & & $161(21.3)$ & $398(24.9)$ & \\
\hline 3 & $173(19.2)$ & $255(17.5)$ & & $137(18.1)$ & $291(18.2)$ & \\
\hline 4 & $141(15.7)$ & $284(19.5)$ & & $133(17.6)$ & $292(18.3)$ & \\
\hline 5 (most vulnerable) & $108(12.0)$ & $258(17.7)$ & $<0.001$ & $93(12.3)$ & $273(17.1)$ & $<0.001$ \\
\hline $\mathrm{PM}_{2.5}\left(\mu \mathrm{g} / \mathrm{m}^{3}\right) ;$ mean $(\mathrm{SD})$ & $17(2.5)$ & $17.4(2.5)$ & $<0.001$ & $16.5(2.2)$ & $17.6(2.6)$ & $<0.001$ \\
\hline $\mathrm{NO}_{2}\left(\mu \mathrm{g} / \mathrm{m}^{3}\right) ;$ mean $(\mathrm{SD})$ & $39.8(6.3)$ & $39.8(6.1)$ & 0.932 & $39.2(6.2)$ & $40.1(6.2)$ & 0.002 \\
\hline
\end{tabular}

BMI: Body mass Index; SD: Standard deviation; WHR: waist-to-hip ratio; NDVI: Normalized difference vegetation index; IQR: Interquartile range; METs: metabolic equivalent of task. $\mathrm{PM}_{2.5}$ : particulate matter less than $2.5 \mu \mathrm{m} ; \mathrm{NO}_{2}$ : nitrogen dioxide. Chi square $\mathrm{p}$-value for categorical variables and t-test $\mathrm{p}$-value for continuous variables 
Table 2. Association between access to green spaces within $300 \mathrm{~m}$ from the current residence and excess weight and abdominal obesity in the overall population and stratified by sex

\begin{tabular}{|c|c|c|c|c|c|c|c|c|c|}
\hline \multirow[b]{2}{*}{ Outcome } & \multicolumn{4}{|c|}{ Overall population, $n=2354$} & \multicolumn{4}{|l|}{ Stratified by sex } & \multirow[b]{2}{*}{$\begin{array}{c}\text { p-value for } \\
\text { interaction (LRT) }\end{array}$} \\
\hline & $\begin{array}{l}\text { Basic }^{\mathrm{a}} \\
\text { OR }(95 \% \mathrm{CI})\end{array}$ & $\mathrm{p}$-value & $\begin{array}{l}\text { Adjusted }{ }^{\mathrm{b}} \\
\text { OR }(95 \% \mathrm{CI}) \\
\end{array}$ & $\mathrm{p}$-value & $\begin{array}{l}\text { Men, } n=1223^{c} \\
\text { OR }(95 \% \mathrm{CI})\end{array}$ & $\mathrm{p}$-value & $\begin{array}{l}\text { Women, } \mathrm{n}=1131 \\
\text { OR }(95 \% \mathrm{CI})\end{array}$ & p-value & \\
\hline \multicolumn{10}{|c|}{ Excess weight } \\
\hline No & 1 (ref) & & 1 (ref) & & 1 (ref) & & 1 (ref) & & \\
\hline Yes & $0.86(0.64-1.15)$ & 0.318 & $0.82(0.63-1.07)$ & 0.143 & $0.92(0.64-1.32)$ & 0.654 & $0.73(0.51-1.05)$ & 0.092 & 0.373 \\
\hline \multicolumn{10}{|c|}{ Abdominal obesity } \\
\hline No & 1 (ref) & & 1 (ref) & & 1 (ref) & & 1 (ref) & & \\
\hline Yes & $0.69(0.46-1.02)$ & 0.066 & $0.68(0.45-1.01)$ & 0.057 & $1.06(0.59-1.91)$ & 0.835 & $0.55(0.35-0.87)$ & 0.010 & 0.056 \\
\hline
\end{tabular}

OR: Odds ratio; 95\%CI: 95\% confidence interval. ${ }^{a}$ Basic model (or crude model, adjusted only for a priori confounders): age and sex. ${ }^{\mathrm{b}}$ Fully adjusted model (adjusted for all potential confounders according to the DAG): adjusted for sex, age, level of education, individual socio-economic status, area level economic status. ${ }^{\mathrm{c}}$ Models stratified by sex adjusted for age, level of education, individual socio-economic status and area level economic status. All models included catchment area as random effect. 
Table 3. Interaction between polygenic risk score and access to green urban areas within $300 \mathrm{~m}$ of the residence

\begin{tabular}{lccc} 
Outcomes & $\begin{array}{l}\text { Low polygenic risk } \\
\text { score }(<75 \%), \mathrm{n}=1271 \\
\text { OR }(95 \% \mathrm{CI}){ }^{\mathrm{a}}\end{array}$ & $\begin{array}{c}\text { High polygenic risk } \\
\text { score }(>75 \%), \mathrm{n}=382 \\
\text { OR }(95 \% \mathrm{CI}){ }^{\mathrm{a}}\end{array}$ & $\begin{array}{c}\text { p-value } \\
\text { LRT, } 2 \mathrm{df}^{\mathrm{b}}\end{array}$ \\
\hline Excess weight & $0.92(0.59-1.45)$ & $0.83(0.36-1.91)$ & 0.825 \\
Abdominal obesity & $0.64(0.35-1.18)$ & $0.32(0.10-1.06)$ & 0.285 \\
\hline
\end{tabular}

OR: Odds ratio comparing yes versus no categories. 95\%CI: 95\% confidence interval. LRT: Likelihood ratio test; df: degrees of freedom. ${ }^{\text {a }}$ Effect of the access to green urban areas within $300 \mathrm{~m}$ of the residence on obesity for each stratum of polygenic risk score. Model with interaction term (green spaces*genetic score), adjusted for sex, age, level of education, individual socio-economic status, area level economic status (catchment area as random effect); ${ }^{b}$ p-value of LRT for the interaction term 
Table 4. Results of the mediation analysis between access to green spaces within $300 \mathrm{~m}$ from the current residence and excess weight and abdominal obesity considering different potential mediators

\begin{tabular}{llccc} 
& & \multicolumn{1}{c}{ Total Effect } & Indirect Effect & Direct Effect \\
\cline { 3 - 5 } Outcome & Mediator & OR $(95 \% \mathrm{CI})^{\mathrm{a}}$ & $\mathrm{OR}(95 \% \mathrm{CI})^{\mathrm{a}}$ & $\mathrm{OR}(95 \% \mathrm{CI})^{\mathrm{a}}$ \\
\hline \multirow{3}{*}{ Excess weight } & Levels of PA (low & & & \\
& vs. high) & $0.85(0.61,1.15)$ & $1.01(0.98,1.03)$ & $0.85(0.61,1.14)$ \\
& $\mathrm{NO}_{2}\left(\mu \mathrm{g} / \mathrm{m}^{3}\right)$ & $0.85(0.61,1.15)$ & $1.00(0.98,1.01)$ & $0.85(0.61,1.15)$ \\
& $\mathrm{PM}_{2.5}\left(\mu \mathrm{g} / \mathrm{m}^{3}\right)$ & $0.85(0.61,1.15)$ & $0.99(0.97,1.01)$ & $0.86(0.61,1.16)$ \\
\hline $\begin{array}{l}\text { Abdominal } \\
\text { obesity }\end{array}$ & $\mathrm{Physical} \mathrm{activity}$ & $0.80(0.51,1.28)$ & $1.01(0.98,1.04)$ & $0.80(0.51,1.20)$ \\
& $\mathrm{NO}_{2}\left(\mu \mathrm{g} / \mathrm{m}^{3}\right)$ & $0.81(0.51,1.29)$ & $1.00(0.99,1.02)$ & $0.80(0.50,1.22)$ \\
& $\mathrm{PM}_{2.5}\left(\mu \mathrm{g} / \mathrm{m}^{3}\right)$ & $0.80(0.51,1.26)$ & $1.02(1.00,1.07)$ & $0.78(0.49,1.20)$ \\
\hline
\end{tabular}

OR: Odds ratio; 95\%CI: 95\% confidence interval; PA: physical activity; $\mathrm{PM}_{2.5}$ : particulate matter less than $2.5 \mu \mathrm{m} ; \mathrm{NO}_{2}$ : nitrogen dioxide. ${ }^{\mathrm{a}}$ 95\% CI were calculated using bootstrap procedure. 
Table 5. Association between surrounding greenness within $300 \mathrm{~m}$ from the current residence and excess weight and abdominal obesity in the overall population and stratified by sex

\begin{tabular}{|c|c|c|c|c|c|c|c|c|c|}
\hline \multirow{3}{*}{ Outcome } & \multicolumn{4}{|c|}{ Overall population, $\mathrm{n}=2354$} & \multicolumn{5}{|l|}{ Stratified by sex } \\
\hline & \multicolumn{2}{|l|}{ Basic $^{\text {a }}$} & \multicolumn{2}{|l|}{ Adjusted $^{\mathrm{b}}$} & \multicolumn{2}{|l|}{ Men, $n=1223^{c}$} & \multicolumn{2}{|l|}{ Women, $\mathrm{n}=1131^{\mathrm{c}}$} & \multirow{2}{*}{$\begin{array}{l}\mathrm{p} \text {-value for } \\
\text { interaction (LRT) }\end{array}$} \\
\hline & OR $(95 \% \mathrm{CI})$ & p-value & OR $(95 \% \mathrm{CI})$ & $p$-value & OR $(95 \% \mathrm{CI})$ & p-value & OR $(95 \% \mathrm{CI})$ & $\mathrm{p}$-value & \\
\hline \multicolumn{10}{|c|}{ Excess weight } \\
\hline No & 1 (ref) & & 1 (ref) & & 1 (ref) & & 1 (ref) & & \\
\hline Yes & $0.96(0.85-1.09)$ & 0.540 & $0.99(0.88-1.11)$ & 0.875 & $1.11(0.94-1.32)$ & 0.218 & $0.91(0.78-1.05)$ & 0.199 & 0.056 \\
\hline \multicolumn{10}{|c|}{ Abdominal obesity } \\
\hline No & 1 (ref) & & 1 (ref) & & 1 (ref) & & 1 (ref) & & \\
\hline Yes & $0.89(0.77-1.02)$ & 0.095 & $0.91(0.79-1.05)$ & 0.186 & $1.09(0.87-1.37)$ & 0.445 & $0.82(0.69-0.97)$ & 0.023 & 0.021 \\
\hline
\end{tabular}

OR: Odds ratio, increase is per $1 \mathrm{IQR}$ based on the NDVI on all the study population in the $300 \mathrm{~m}$ buffer around the residence; $95 \% \mathrm{CI}$ : $95 \%$ confidence interval. ${ }^{a}$ Basic model: model adjusted for age and sex. ${ }^{\mathrm{b}}$ Fully adjusted model: adjusted for sex, age, level of education, individual socio-economic status, area level economic status. ${ }^{\mathrm{c}}$ Models stratified by sex adjusted for age, level of education, individual socio-economic status and area level economic status. Catchment area included as random effect. All models included catchment area as random effect. 
Table 6. Interaction between polygenic risk score and surrounding greenness within $300 \mathrm{~m}$ of the residence

\begin{tabular}{llll} 
& $\begin{array}{l}\text { Low polygenic risk } \\
\text { score }(<75 \%), \mathrm{n}=1271\end{array}$ & $\begin{array}{l}\text { High polygenic risk } \\
\text { score }(>75 \%), \mathrm{n}=382\end{array}$ & $\begin{array}{c}\text { p-value } \\
\text { LRT, 2 df }\end{array}$ \\
\cline { 2 - 3 } Outcomes & OR $(95 \% \mathrm{CI})^{\mathrm{a}}$ & OR $(95 \% \mathrm{CI})^{\mathrm{a}}$ & \\
\hline Excess weight & $0.96(0.82-1.12)$ & $0.89(0.69-1.16)$ & 0.613 \\
Abdominal obesity & $0.80(0.65-0.99)$ & $0.68(0.50-0.93)$ & 0.320 \\
\hline
\end{tabular}

OR: Odds ratio, increase is per 1 IQR based on the NDVI on all the study population in the $300 \mathrm{~m}$ buffer around the residence; 95\%CI: 95\% confidence interval; LRT: Likelihood ratio test; $\mathrm{df}$ : degrees of freedom. ${ }^{\text {a }}$ Effect of surrounding greenness within 300 $\mathrm{m}$ of the residence on obesity for each stratum of polygenic risk score. Model with interaction term (surrounding greenness * genetic score), adjusted for sex, age, level of education, individual socio-economic status, area level economic status (catchment area as random effect); ${ }^{b}$ p-value of LRT for the interaction term 
Table 7. Results of the mediation analysis between surrounding greenness within $300 \mathrm{~m}$ from the current residence and excess weight and abdominal obesity considering different potential mediators

\begin{tabular}{llccc}
\cline { 3 - 5 } Outcome & & Total Effect & Indirect Effect & Direct Effect \\
\cline { 3 - 5 } Excess weight & Levels of PA (low & OR $(95 \% \mathrm{CI})^{\mathrm{a}}$ & $\mathrm{OR}(95 \% \mathrm{CI})^{\mathrm{a}}$ & ${\text { OR }(95 \% \mathrm{CI})^{\mathrm{a}}}$ \\
& vs. high) & $1.05(0.94,1.19)$ & $1.00(0.98,1.00)$ & $1.06(0.94,1.19)$ \\
& $\mathrm{NO}_{2}\left(\mu \mathrm{g} / \mathrm{m}^{3}\right)$ & $1.05(0.94,1.19)$ & $1.03(0.98,1.07)$ & $1.02(0.89,1.16)$ \\
& $\mathrm{PM}_{2.5}\left(\mu \mathrm{g} / \mathrm{m}^{3}\right)$ & $1.05(0.94,1.18)$ & $1.01(0.98,1.04)$ & $1.04(0.92,1.19)$ \\
\hline $\begin{array}{l}\text { Abdominal } \\
\text { obesity }\end{array}$ & $\mathrm{Physical} \mathrm{activity}^{*}$ & $0.96(0.82,1.12)$ & $0.99(0.98,1.01)$ & $0.96(0.82,1.11)$ \\
& $\mathrm{NO}_{2}\left(\mu \mathrm{g} / \mathrm{m}^{3}\right)$ & $0.95(0.81,1.11)$ & $0.98(0.92,1.04)$ & $0.97(0.82,1.13)$ \\
& $\mathrm{PM}_{2.5}\left(\mu \mathrm{g} / \mathrm{m}^{3}\right)$ & $0.95(0.82,1.11)$ & $0.97(0.94,1.00)$ & $0.98(0.82,1.13)$ \\
\hline
\end{tabular}

OR: Odds ratio; 95\%CI: 95\% confidence interval; PA: physical activity; $\mathrm{PM}_{2.5}$ : particulate matter less than $2.5 \mu \mathrm{m} ; \mathrm{NO}_{2}$ : nitrogen dioxide. ${ }^{\mathrm{a}}$ 95\% CI were calculated using bootstrap procedure. 


\section{Acknowledgments}

ISGlobal is a member of the CERCA Programme, Generalitat de Catalunya. The study was conducted with the Support of Department of Health, Catalan Government grant SLT002/16/00223. The study was partially funded by the "Accion Transversal del Cancer", approved on the Spanish Ministry Council on the 11th October 2007, by the Instituto de Salud Carlos III-FEDER (PI08/1770, PI08/0533, PI08/1359, PS09/00773Cantabria, PS09/01903-Valencia, PI11/01403, PI11/01889-FEDER, PI11/01810, PI12/00488, PI12/00265, PI12/01270, PI12/00715, PI14/01219, PI14/0613, PI15/00069), by the Fundación Marqués de Valdecilla (API 10/09), by the ICGC International Cancer Genome Consortium CLL (The ICGC CLL-Genome Project is funded by Spanish Ministerio de Economía y Competitividad (MINECO) through the Instituto de Salud Carlos III (ISCIII) and Red Temática de Investigación del Cáncer (RTICC) del ISCIII (RD12/0036/0036)), by the Junta de Castilla y León (LE22A10-2), by the Consejería de Salud of the Junta de Andalucía (PI-0571-2009, PI-0306-2011, salud201200057018tra), by the Conselleria de Sanitat of the Generalitat Valenciana (AP_061/10), by the Recercaixa (2010ACUP 00310), by the Regional Government of the Basque Country, by the Consejería de Sanidad de la Región de Murcia, by the European Commission grants FOOD-CT-2006-036224-HIWATE, by the Spanish Association Against Cancer (AECC) Scientific Foundation, by the Catalan Government- Agency for Management of University and Research Grants (AGAUR) grants 2017SGR723 and 2014SGR850, by the Fundación Caja de Ahorros de Asturias and by the University of Oviedo. ISGlobal is a member of the CERCA Programme, Generalitat de Catalunya. Biological samples were stored at the biobanks supported by Instituto de Salud Carlos III- FEDER: Parc de Salut MAR Biobank (MARBiobanc) (RD09/0076/00036), "Biobanco La Fe" (RD 09 0076/00021) and FISABIO Biobank (RD09 0076/00058). Also at the Public Health Laboratory from Gipuzkoa, the Basque Biobank, the ICOBIOBANC (sponsored by the Catalan Institute of Oncology), the IUOPA Biobank from the University of Oviedo and the ISCIII Biobank. The SNP genotyping services were provided by the Spanish "Centro Nacional de Genotipado" (CEGEN-ISCIII).

\section{Declaration of competing financial interests (CFI)}

The authors declare they have no actual or potential competing financial interests. 


\section{References}

Abadi, A., Alyass, A., Robiou du Pont, S., Bolker, B., Singh, P., Mohan, V., Diaz, R., Engert, J.C., Yusuf, S., Gerstein, H.C., Anand, S.S., Meyre, D., 2017. Penetrance of Polygenic Obesity Susceptibility Loci across the Body Mass Index Distribution. Am. J. Hum. Genet. 101, 925-938. https://doi.org/10.1016/j.ajhg.2017.10.007

Abdelaal, M., le Roux, C., Docherty, N., 2017. Morbidity and mortality associated with obesity. Ann. Transl. Med. 5, 161.

Amrhein, V., Greenland, S., McShane, B., 2019. Scientists rise up against statistical significance. Nature 567, 305-307. https://doi.org/10.1038/d41586-019-00857-9

An, R., Wang, J., Ashrafi, S.A., Yang, Y., Guan, C., 2018. Chronic Noise Exposure and Adiposity: A Systematic Review and Meta-analysis. Am. J. Prev. Med. 55, 403411. https://doi.org/10.1016/j.amepre.2018.04.040

Aranceta-Bartrina, J., Pérez-Rodrigo, C., Alberdi-Aresti, G., Ramos-Carrera, N., Lázaro-Masedo, S., 2016. Prevalence of General Obesity and Abdominal Obesity in the Spanish Adult Population (Aged 25-64 Years) 2014-2015: The ENPE Study. Rev. Esp. Cardiol. (Engl. Ed). 69, 579-87. https://doi.org/10.1016/j.rec.2016.02.009

Astell-Burt, T., Feng, X., Kolt, G.S., 2014. Greener neighborhoods, slimmer people? Evidence from 246920 Australians. Int. J. Obes. 38, 156-159. https://doi.org/10.1038/ijo.2013.64

Ayanian, J.Z., Block, J.P., He, Y., Zaslavsky, A.M., Ding, L., 2009. Psychosocial stress and change in weight among US adults. Am. J. Epidemiol. 170, 181-192. https://doi.org/10.1093/aje/kwp104

Beelen, R., Hoek, G., Vienneau, D., Eeftens, M., Dimakopoulou, K., Pedeli, X., Tsai, M.-Y., Künzli, N., Schikowski, T., Marcon, A., Eriksen, K.T., Raaschou-Nielsen, O., Stephanou, E., Patelarou, E., Lanki, T., Yli-Tuomi, T., Declercq, C., Falq, G., Stempfelet, M., Birk, M., Cyrys, J., von Klot, S., Nádor, G., Varró, M.J., Dėdelè, A., Gražulevičienė, R., Mölter, A., Lindley, S., Madsen, C., Cesaroni, G., Ranzi, A., Badaloni, C., Hoffmann, B., Nonnemacher, M., Krämer, U., Kuhlbusch, T., Cirach, M., de Nazelle, A., Nieuwenhuijsen, M., Bellander, T., Korek, M., Olsson, D., Strömgren, M., Dons, E., Jerrett, M., Fischer, P., Wang, M., Brunekreef, B., de Hoogh, K., 2013. Development of NO2 and NOx land use regression models for estimating air pollution exposure in 36 study areas in Europe - The ESCAPE project. Atmos. Environ. 72, 10-23.

https://doi.org/10.1016/j.atmosenv.2013.02.037

Castaño-Vinyals, G., Aragonés, N., Pérez-Gómez, B., Martín, V., Llorca, J., Moreno, V., Altzibar, J.M., Ardanaz, E., de Sanjosé, S., Jiménez-Moleón, J.J., Tardón, A., Alguacil, J., Peiró, R., Marcos-Gragera, R., Navarro, C., Pollán, M., Kogevinas, M., 2015. Population-based multicase-control study in common tumors in Spain (MCC-Spain): rationale and study design. Gac. Sanit. https://doi.org/10.1016/j.gaceta.2014.12.003

Dadvand, P., Bartoll, X., Basagaña, X., Dalmau-Bueno, A., Martinez, D., Ambros, A., Cirach, M., Triguero-Mas, M., Gascon, M., Borrell, C., Nieuwenhuijsen, M.J., 2016. Green spaces and General Health: Roles of mental health status, social support, and physical activity. Environ. Int. 91, 161-167. https://doi.org/10.1016/j.envint.2016.02.029 
Dadvand, P., Sunyer, J., Basaga??a, X., Ballester, F., Lertxundi, A., Fern??ndezSomoano, A., Estarlich, M., Garc??a-Esteban, R., Mendez, M.A., Nieuwenhuijsen, M.J., 2012. Surrounding greenness and pregnancy outcomes in four Spanish birth cohorts. Environ. Health Perspect. 120, 1481-1487. https://doi.org/10.1289/ehp.1205244

Dallman, M.F., Pecoraro, N., Akana, S.F., la Fleur, S.E., Gomez, F., Houshyar, H., Bell, M.E., Bhatnagar, S., Laugero, K.D., Manalo, S., 2003. Chronic stress and obesity: A new view of "comfort food." Proc. Natl. Acad. Sci. 100, 11696-11701. https://doi.org/10.1073/pnas.1934666100

Devaux, M., Sassi, F., 2013. Social inequalities in obesity and overweight in 11 OECD countries. Eur. J. Public Health 23, 464-469. https://doi.org/10.1093/eurpub/ckr058

Eeftens, M., Beelen, R., de Hoogh, K., Bellander, T., Cesaroni, G., Cirach, M., Declercq, C., Dedele, A., Dons, E., de Nazelle, A., others, 2012. Development of land use regression models for PM2. 5, PM2. 5 absorbance, PM10 and PMcoarse in 20 European study areas; results of the ESCAPE project. Environ. Sci. Technol. 46, 11195-11205. https://doi.org/10.1021/es301948k

Ellaway, A., Macintyre, S., Bonnefoy, X., 2005. Graffiti, greenery, and obesity in adults: secondary analysis of European cross sectional survey. BMJ 331, 611-612. https://doi.org/doi 10.1136/bmj.38575.664549.F7

European Environment Agency, 2006. MAPPING GUIDE FOR A EUROPEAN URBAN ATLAS.

Fioravanti, S., Cesaroni, G., Badaloni, C., Michelozzi, P., Forastiere, F., Porta, D., 2018. Traffic-related air pollution and childhood obesity in an Italian birth cohort. Environ. Res. 160, 479-486. https://doi.org/10.1016/j.envres.2017.10.003

Frumkin, H., Bratman, G.N., Brewslow, S.J., Cochran, B., Kahn, P.H., Lawler, J.J., Levin, P.S., Tandon, P.S., Varanasi, U., Wolf, K.L., Wood, S. a., 2017. Nature contact and human health: a research agenda. Environ. Heal. Perpsectives in press, 1-18. https://doi.org/10.1289/EHP1663

Global BMI Mortality Collaboration, 2016. Body-mass index and all-cause mortality: individual-participant-data meta-analysis of 239 prospective studies in four continents. Lancet 388, 776-786. https://doi.org/10.1016/S0140-6736(16)30175-1

Greenland, S., Daniel, R., Pearce, N., Greenland, S., Daniel, R., Pearce, N., 2016. Outcome modelling strategies in epidemiology: traditional methods and basic alternatives. Int. J. Epidemiol. 1-11. https://doi.org/10.1093/ije/dyw040

Grove, M.L., Yu, B., Cochran, B.J., Haritunians, T., Bis, J.C., Taylor, K.D., Hansen, M., Borecki, I.B., Cupples, L.A., Fornage, M., Gudnason, V., Harris, T.B., Kathiresan, S., Kraaij, R., Launer, L.J., Levy, D., Liu, Y., Mosley, T., Peloso, G.M., Psaty, B.M., Rich, S.S., Rivadeneira, F., Siscovick, D.S., Smith, A. V., Uitterlinden, A., van Duijn, C.M., Wilson, J.G., O’Donnell, C.J., Rotter, J.I., Boerwinkle, E., 2013. Best Practices and Joint Calling of the HumanExome BeadChip: The CHARGE Consortium. PLoS One 8, e68095. https://doi.org/10.1371/journal.pone.0068095

Harding, J.L., Backholer, K., Williams, E.D., Peeters, A., Cameron, A.J., Hare, M.J.L., Shaw, J.E., Magliano, D.J., 2014. Psychosocial stress is positively associated with body mass index gain over 5 years: Evidence from the longitudinal AusDiab study. 
Obesity 22, 277-286. https://doi.org/10.1002/oby.20423

Hartig, T., Mitchell, R., de Vries, S., Frumkin, H., 2014. Nature and Health. Ssrn. https://doi.org/10.1146/annurev-publhealth-032013-182443

Hayes, A.F., 2009. Beyond Baron and Kenny: Statistical Mediation Analysis in the New Millennium. Commun. Monogr. 76, 408-420. https://doi.org/10.1080/03637750903310360

Helbich, M., 2019. Spatiotemporal Contextual Uncertainties in Green Space Exposure Measures: Exploring a Time Series of the Normalized Difference Vegetation Indices. Int. J. Environ. Res. Public Health 16. https://doi.org/10.3390/ijerph16050852

Humpel, N., Owen, N., Leslie, E., 2002. Environmental Factors Associated with Adults ' Participation in Physical Activity A Review 22.

James, P., Hart, J.E., Banay, R.F., Laden, F., 2016. Exposure to greenness and mortality in a nationwide prospective cohort study of women. Environ. Health Perspect. 124, 1344-1352. https://doi.org/10.1289/ehp.1510363

Jerrett, M., McConnell, R., Wolch, J., Chang, R., Lam, C., Dunton, G., Gilliland, F., Lurmann, F., Islam, T., Berhane, K., 2014. Traffic-related air pollution and obesity formation in children: A longitudinal, multilevel analysis. Environ. Heal. A Glob. Access Sci. Source 13, 1-9. https://doi.org/10.1186/1476-069X-13-49

Kanter, R., Caballero, B., 2012. Global gender disparities in obesity: a review. Adv. Nutr. 3, 491-8. https://doi.org/10.3945/an.112.002063

Kraft, P., Yen, Y., Stram, O., Morrison, J., 2007. Exploiting Gene-Environment Interaction 02115, 111-119. https://doi.org/10.1159/000099183

Kuczmarski, M.F., Kuczmarski, R.J., Najjar, M., 2001. Effects of Age on Validity of Self-Reported Height, Weight, and Body Mass Index: Findings from the Third National Health and Nutrition Examination Survey, 1988-1994. J. Am. Diet. Assoc. 101, 28-34. https://doi.org/http://dx.doi.org/10.1016/S00028223(01)00008-6

Lachowycz, K., Jones, A.P., 2011. Greenspace and obesity: A systematic review of the evidence. Obes. Rev. 12, 183-189. https://doi.org/10.1111/j.1467789X.2010.00827.X

Lee, A.C.K., Maheswaran, R., 2011. The health benefits of urban green spaces: a review of the evidence. J. Public Health (Bangkok). 33, 212-222. https://doi.org/10.1093/pubmed/fdq068

Locke, A.E., Kahali, B., Berndt, S.I., Justice, A.E., Pers, T.H., Day, F.R., Powell, C., Vedantam, S., Buchkovich, M.L., Yang, J., Croteau-Chonka, D.C., Esko, T., Fall, T., Ferreira, T., Gustafsson, S., Kutalik, Z., Luan, J., Mägi, R., Randall, J.C., Winkler, T.W., Wood, A.R., Workalemahu, T., Faul, J.D., Smith, J.A., Zhao, J.H., Zhao, W., Chen, J., Fehrmann, R., Hedman, A.K., Karjalainen, J., Schmidt, E.M., Absher, D., Amin, N., Anderson, D., Beekman, M., Bolton, J.L., Bragg-Gresham, J.L., Buyske, S., Demirkan, A., Deng, G., Ehret, G.B., Feenstra, B., Feitosa, M.F., Fischer, K., Goel, A., Gong, J., Jackson, A.U., Kanoni, S., Kleber, M.E., Kristiansson, K., Lim, U., Lotay, V., Mangino, M., Leach, I.M., Medina-Gomez, C., Medland, S.E., Nalls, M.A., Palmer, C.D., Pasko, D., Pechlivanis, S., Peters, M.J., Prokopenko, I., Shungin, D., Stančáková, A., Strawbridge, R.J., Sung, Y.J., Tanaka, Toshiko, Teumer, A., Trompet, S., van der Laan, S.W., van Setten, J., Van 
Vliet-Ostaptchouk, J. V, Wang, Z., Yengo, L., Zhang, W., Isaacs, A., Albrecht, E., Ärnlöv, J., Arscott, G.M., Attwood, A.P., Bandinelli, S., Barrett, A., Bas, I.N., Bellis, C., Bennett, A.J., Berne, C., Blagieva, R., Blüher, M., Böhringer, S., Bonnycastle, L.L., Böttcher, Y., Boyd, H.A., Bruinenberg, M., Caspersen, I.H., Chen, Y.-D.I., Clarke, R., Daw, E.W., de Craen, A.J.M., Delgado, G., Dimitriou, M., Doney, A.S.F., Eklund, N., Estrada, K., Eury, E., Folkersen, L., Fraser, R.M., Garcia, M.E., Geller, F., Giedraitis, V., Gigante, B., Go, A.S., Golay, A., Goodall, A.H., Gordon, S.D., Gorski, M., Grabe, H.-J., Grallert, H., Grammer, T.B., Gräßler, J., Grönberg, H., Groves, C.J., Gusto, G., Haessler, J., Hall, P., Haller, T., Hallmans, G., Hartman, C.A., Hassinen, M., Hayward, C., Heard-Costa, N.L., Helmer, Q., Hengstenberg, C., Holmen, O., Hottenga, J.-J., James, A.L., Jeff, J.M., Johansson, A., Jolley, J., Juliusdottir, T., Kinnunen, L., Koenig, W., Koskenvuo, M., Kratzer, W., Laitinen, J., Lamina, C., Leander, K., Lee, N.R., Lichtner, P., Lind, L., Lindström, J., Lo, K.S., Lobbens, S., Lorbeer, R., Lu, Y., Mach, F., Magnusson, P.K.E., Mahajan, A., McArdle, W.L., McLachlan, S., Menni, C., Merger, S., Mihailov, E., Milani, L., Moayyeri, A., Monda, K.L., Morken, M.A., Mulas, A., Müller, G., Müller-Nurasyid, M., Musk, A.W., Nagaraja, R., Nöthen, M.M., Nolte, I.M., Pilz, S., Rayner, N.W., Renstrom, F., Rettig, R., Ried, J.S., Ripke, S., Robertson, N.R., Rose, L.M., Sanna, S., Scharnagl, H., Scholtens, S., Schumacher, F.R., Scott, W.R., Seufferlein, T., Shi, J., Smith, A.V., Smolonska, J., Stanton, A. V, Steinthorsdottir, V., Stirrups, K., Stringham, H.M., Sundström, J., Swertz, M.A., Swift, A.J., Syvänen, A.-C., Tan, S.-T., Tayo, B.O., Thorand, B., Thorleifsson, G., Tyrer, J.P., Uh, H.-W., Vandenput, L., Verhulst, F.C., Vermeulen, S.H., Verweij, N., Vonk, J.M., Waite, L.L., Warren, H.R., Waterworth, D., Weedon, M.N., Wilkens, L.R., Willenborg, C., Wilsgaard, T., Wojczynski, M.K., Wong, A., Wright, A.F., Zhang, Q., LifeLines Cohort Study, Brennan, E.P., Choi, M., Dastani, Z., Drong, A.W., Eriksson, P., Franco-Cereceda, A., Gådin, J.R., Gharavi, A.G., Goddard, M.E., Handsaker, R.E., Huang, J., Karpe, F., Kathiresan, S., Keildson, S., Kiryluk, K., Kubo, M., Lee, J.-Y., Liang, L., Lifton, R.P., Ma, B., McCarroll, S.A., McKnight, A.J., Min, J.L., Moffatt, M.F., Montgomery, G.W., Murabito, J.M., Nicholson, G., Nyholt, D.R., Okada, Y., Perry, J.R.B., Dorajoo, R., Reinmaa, E., Salem, R.M., Sandholm, N., Scott, R.A., Stolk, L., Takahashi, A., Tanaka, Toshihiro, van 't Hooft, F.M., Vinkhuyzen, A.A.E., Westra, H.-J., Zheng, W., Zondervan, K.T., ADIPOGen Consortium, AGEN-BMI Working Group, CARDIOGRAMplusC4D Consortium, CKDGen Consortium, GLGC, ICBP, MAGIC Investigators, MuTHER Consortium, MIGen Consortium, PAGE Consortium, ReproGen Consortium, GENIE Consortium, International Endogene Consortium, Heath, A.C., Arveiler, D., Bakker, S.J.L., Beilby, J., Bergman, R.N., Blangero, J., Bovet, P., Campbell, H., Caulfield, M.J., Cesana, G., Chakravarti, A., Chasman, D.I., Chines, P.S., Collins, F.S., Crawford, D.C., Cupples, L.A., Cusi, D., Danesh, J., de Faire, U., den Ruijter, H.M., Dominiczak, A.F., Erbel, R., Erdmann, J., Eriksson, J.G., Farrall, M., Felix, S.B., Ferrannini, E., Ferrières, J., Ford, I., Forouhi, N.G., Forrester, T., Franco, O.H., Gansevoort, R.T., Gejman, P. V, Gieger, C., Gottesman, O., Gudnason, V., Gyllensten, U., Hall, A.S., Harris, T.B., Hattersley, A.T., Hicks, A.A., Hindorff, L.A., Hingorani, A.D., Hofman, A., Homuth, G., Hovingh, G.K., Humphries, S.E., Hunt, S.C., Hyppönen, E., Illig, T., Jacobs, K.B., Jarvelin, M.-R., Jöckel, K.-H., Johansen, B., Jousilahti, P., Jukema, J.W., Jula, A.M., Kaprio, J., Kastelein, J.J.P., Keinanen-Kiukaanniemi, S.M., Kiemeney, L.A., Knekt, P., Kooner, J.S., Kooperberg, C., Kovacs, P., Kraja, A.T., Kumari, M., Kuusisto, J., Lakka, T.A., 
Langenberg, C., Marchand, L. Le, Lehtimäki, T., Lyssenko, V., Männistö, S., Marette, A., Matise, T.C., McKenzie, C.A., McKnight, B., Moll, F.L., Morris, A.D., Morris, A.P., Murray, J.C., Nelis, M., Ohlsson, C., Oldehinkel, A.J., Ong, K.K., Madden, P.A.F., Pasterkamp, G., Peden, J.F., Peters, A., Postma, D.S., Pramstaller, P.P., Price, J.F., Qi, L., Raitakari, O.T., Rankinen, T., Rao, D.C., Rice, T.K., Ridker, P.M., Rioux, J.D., Ritchie, M.D., Rudan, I., Salomaa, V., Samani, N.J., Saramies, J., Sarzynski, M.A., Schunkert, H., Schwarz, P.E.H., Sever, P., Shuldiner, A.R., Sinisalo, J., Stolk, R.P., Strauch, K., Tönjes, A., Trégouët, D.-A., Tremblay, A., Tremoli, E., Virtamo, J., Vohl, M.-C., Völker, U., Waeber, G., Willemsen, G., Witteman, J.C., Zillikens, M.C., Adair, L.S., Amouyel, P., Asselbergs, F.W., Assimes, T.L., Bochud, M., Boehm, B.O., Boerwinkle, E., Bornstein, S.R., Bottinger, E.P., Bouchard, C., Cauchi, S., Chambers, J.C., Chanock, S.J., Cooper, R.S., de Bakker, P.I.W., Dedoussis, G., Ferrucci, L., Franks, P.W., Froguel, P., Groop, L.C., Haiman, C.A., Hamsten, A., Hui, J., Hunter, D.J., Hveem, K., Kaplan, R.C., Kivimaki, M., Kuh, D., Laakso, M., Liu, Y., Martin, N.G., März, W., Melbye, M., Metspalu, A., Moebus, S., Munroe, P.B., Njølstad, I., Oostra, B.A., Palmer, C.N.A., Pedersen, N.L., Perola, M., Pérusse, L., Peters, U., Power, C., Quertermous, T., Rauramaa, R., Rivadeneira, F., Saaristo, T.E., Saleheen, D., Sattar, N., Schadt, E.E., Schlessinger, D., Slagboom, P.E., Snieder, H., Spector, T.D., Thorsteinsdottir, U., Stumvoll, M., Tuomilehto, J., Uitterlinden, A.G., Uusitupa, M., van der Harst, P., Walker, M., Wallaschofski, H., Wareham, N.J., Watkins, H., Weir, D.R., Wichmann, H.-E., Wilson, J.F., Zanen, P., Borecki, I.B., Deloukas, P., Fox, C.S., Heid, I.M., O’Connell, J.R., Strachan, D.P., Stefansson, K., van Duijn, C.M., Abecasis, G.R., Franke, L., Frayling, T.M., McCarthy, M.I., Visscher, P.M., Scherag, A., Willer, C.J., Boehnke, M., Mohlke, K.L., Lindgren, C.M., Beckmann, J.S., Barroso, I., North, K.E., Ingelsson, E., Hirschhorn, J.N., Loos, R.J.F., Speliotes, E.K., 2015. Genetic studies of body mass index yield new insights for obesity biology. Nature 518, 197-206. https://doi.org/10.1038/nature14177

MacMahon, S., Baigent, C., Duffy, S., Rodgers, A., Tominaga, S., Chambless, L., De Backer, G., De Bacquer, D., Kornitzer, M., Whincup, P., Wannamethee, S.G., Morris, R., Wald, N., Morris, J., Law, M., Knuiman, M., Bartholomew, H., Davey Smith, G., Sweetnam, P., Elwood, P., Yarnell, J., Kronmal, R., Kromhout, D., Sutherland, S., Keil, J., Jensen, G., Schnohr, P., Hames, C., Tyroler, A., Aromaa, A., Knekt, P., Reunanen, A., Tuomilehto, J., Jousilahti, P., Vartiainen, E., Puska, P., Kuznetsova, T., Richart, T., Staessen, J., Thijs, L., J??rgensen, T., Thomsen, T., Sharp, D., Curb, J.D., Qizilbash, N., Iso, H., Sato, S., Kitamura, A., Naito, Y., Benetos, A., Guize, L., Goldbourt, U., Tomita, M., Nishimoto, Y., Murayama, T., Criqui, M., Davis, C., Hart, C., Davey Smith, G., Hole, D., Gillis, C., Jacobs, D., Blackburn, H., Luepker, R., Neaton, J., Eberly, L., Cox, C., Levy, D., D’Agostino, R., Silbershatz, H., Tverdal, A., Selmer, R., Meade, T., Garrow, K., Cooper, J., Speizer, F., Stampfer, M., Menotti, A., Spagnolo, A., Tsuji, I., Imai, Y., Ohkubo, T., Hisamichi, S., Haheim, L., Holme, I., Hjermann, I., Leren, P., Ducimetiere, P., Empana, J., Jamrozik, K., Broadhurst, R., Assmann, G., Schulte, H., Bengtsson, C., Bj??rkelund, C., Lissner, L., Sorlie, P., Garcia-Palmieri, M., Barrett-Connor, E., Criqui, M., Langer, R., Hart, C., Davey Smith, G., Hole, D., Nakachi, K., Imai, K., Fang, X., Li, S., Buzina, R., Nissinen, A., Aravanis, C., Dontas, A., Kafatos, A., Menotti, A., Adachi, H., Toshima, H., Imaizumi, T., Kromhout, D., Nedeljkovic, S., Ostojic, M., Chen, Z., Tunstall-Pedoe, H., Nakayama, T., Yoshiike, N., Yokoyama, T., Date, C., Tanaka, H., Keller, J., Bonaa, K., Arnesen, E., Tunstall- 
Pedoe, H., Rimm, E., Gaziano, M., Buring, J.E., Hennekens, C., T??rnberg, S., Carstensen, J., Shipley, M., Leon, D., Marmot, M., Clarke, R., Collins, R., Emberson, J., Halsey, J., Lewington, S., Palmer, A., Parish, S., Peto, R., Sherliker, P., Whitlock, G., 2009. Body-mass index and cause-specific mortality in 900000 adults: Collaborative analyses of 57 prospective studies. Lancet 373, 1083-1096. https://doi.org/10.1016/S0140-6736(09)60318-4

Markevych, I., Schoierer, J., Hartig, T., Chudnovsky, A., Hystad, P., Dzhambov, A.M., de Vries, S., Triguero-Mas, M., Brauer, M., Nieuwenhuijsen, M.J., Lupp, G., Richardson, E.A., Astell-Burt, T., Dimitrova, D., Feng, X., Sadeh, M., Standl, M., Heinrich, J., Fuertes, E., 2017. Exploring pathways linking greenspace to health: Theoretical and methodological guidance. Environ. Res. 158, 301-317. https://doi.org/10.1016/j.envres.2017.06.028

McAdams, M. a, Van Dam, R.M., Hu, F.B., 2007. Comparison of self-reported and measured BMI as correlates of disease markers in US adults. Obesity (Silver Spring). 15, 188-196. https://doi.org/10.1038/oby.2007.504

Merino Ventosa, M., Urbanos-Garrido, R.M.M.M.V.G.C., 2016. Disentangling effects of socioeconomic status on obesity: A cross-sectional study of the Spanish adult population. Econ. Hum. Biol. 22, 216-224. https://doi.org/10.1016/j.ehb.2016.05.004

Ministry of Public Works (Spain), 2001. Atlas of Urban Vulnerability in Spain [WWW Document]. URL http://atlasvulnerabilidadurbana.fomento.es/\#v=map2;l=en, (accessed 5.25.16).

Ng, M., Fleming, T., Robinson, M., Thomson, B., Graetz, N., 2014. Global, regional and national prevalence of overweight and obesity in children and adults 19802013: A systematic analysis. Lancet 384, 766-781. https://doi.org/10.1016/S01406736(14)60460-8.Global

Nieuwenhuijsen, M.J., Khreis, H., Triguero-Mas, M., Gascon, M., Dadvand, P., 2017. Fifty shades of green. Epidemiology 28, 63-71. https://doi.org/10.1097/EDE.0000000000000549

O’Callaghan-Gordo, C., Kogevinas, M., Cirach, M., Castaño-Vinyals, G., Aragonés, N., Delfrade, J., Fernández-Villa, T., Amiano, P., Dierssen-Sotos, T., Tardon, A., Capelo, R., Peiró-Perez, R., Moreno, V., Roca-Barceló, A., Perez-Gomez, B., Vidan, J., Molina, A.J., Oribe, M., Gràcia-Lavedan, E., Espinosa, A., Valentin, A., Pollán, M., Nieuwenhuijsen, M.J., 2018. Residential proximity to green spaces and breast cancer risk: The multicase-control study in Spain (MCC-Spain). Int. J. Hyg. Environ. Health 0-1. https://doi.org/10.1016/j.ijheh.2018.07.014

Purcell, S., Neale, B., Todd-Brown, K., Thomas, L., Ferreira, M.A.R., Bender, D., Maller, J., Sklar, P., de Bakker, P.I.W., Daly, M.J., Sham, P.C., 2007. PLINK: A Tool Set for Whole-Genome Association and Population-Based Linkage Analyses. Am. J. Hum. Genet. 81, 559-575. https://doi.org/10.1086/519795

Raftopoulou, A., 2017. Geographic determinants of individual obesity risk in Spain: A multilevel approach. Econ. Hum. Biol. 24, 185-193.

https://doi.org/10.1016/j.ehb.2016.12.001

Rask-Andersen, M., Karlsson, T., Ek, W.E., Johansson, Å., 2017. Gene-environment interaction study for BMI reveals interactions between genetic factors and physical activity, alcohol consumption and socioeconomic status. PLoS Genet. 13, 1-20. https://doi.org/10.1371/journal.pgen.1006977 
Richardson, E.A., Mitchell, R., 2010. Gender differences in relationships between urban green space and health in the United Kingdom. Soc. Sci. Med. 71, 568-575. https://doi.org/10.1016/j.socscimed.2010.04.015

Richardson, E.A., Pearce, J., Mitchell, R., Kingham, S., 2013. Role of physical activity in the relationship between urban green space and health. Public Health 127, 318324. https://doi.org/10.1016/j.puhe.2013.01.004

Roskam, A.-J.R., Kunst, A.E., Van Oyen, H., Demarest, S., Klumbiene, J., Regidor, E., Helmert, U., Jusot, F., Dzurova, D., Mackenbach, J.P., 2010. Comparative appraisal of educational inequalities in overweight and obesity among adults in 19 European countries. Int. J. Epidemiol. 39, 392-404. https://doi.org/10.1093/ije/dyp329

Rothman, Kenneth J.; Greenland, Sander; Lash, T.L., 2008. Modern Epidemiology, 3rd editio. ed. Philadelphia.

Rothman, K.J., 2008. BMI-related errors in the measurement of obesity 56-59. https://doi.org/10.1038/ijo.2008.87

Scott, M.M., Dubowitz, T., Cohen, D.A., 2009. Regional differences in walking frequency and BMI: What role does the built environment play for Blacks and Whites? Heal. Place 15, 882-887. https://doi.org/10.1016/j.healthplace.2009.02.010

Speliotes, E.K., Willer, C.J., Berndt, S.I., Monda, K.L., Thorleifsson, G., Jackson, A.U., Allen, H.L., Lindgren, C.M., Luan, J., Mägi, R., Randall, J.C., Vedantam, S., Winkler, T.W., Qi, L., Workalemahu, T., Heid, I.M., Steinthorsdottir, V., Stringham, H.M., Weedon, M.N., Wheeler, E., Wood, A.R., Ferreira, T., Weyant, R.J., Segrè, A. V, Estrada, K., Liang, L., Nemesh, J., Park, J.-H., Gustafsson, S., Kilpeläinen, T.O., Yang, J., Bouatia-Naji, N., Esko, T., Feitosa, M.F., Kutalik, Z., Mangino, M., Raychaudhuri, S., Scherag, A., Smith, A.V., Welch, R., Zhao, J.H., Aben, K.K., Absher, D.M., Amin, N., Dixon, A.L., Fisher, E., Glazer, N.L., Goddard, M.E., Heard-Costa, N.L., Hoesel, V., Hottenga, J.-J., Johansson, Å., Johnson, T., Ketkar, S., Lamina, C., Li, S., Moffatt, M.F., Myers, R.H., Narisu, N., Perry, J.R.B., Peters, M.J., Preuss, M., Ripatti, S., Rivadeneira, F., Sandholt, C., Scott, L.J., Timpson, N.J., Tyrer, J.P., van Wingerden, S., Watanabe, R.M., White, C.C., Wiklund, F., Barlassina, C., Chasman, D.I., Cooper, M.N., Jansson, J.-O., Lawrence, R.W., Pellikka, N., Prokopenko, I., Shi, J., Thiering, E., Alavere, H., Alibrandi, M.T.S., Almgren, P., Arnold, A.M., Aspelund, T., Atwood, L.D., Balkau, B., Balmforth, A.J., Bennett, A.J., Ben-Shlomo, Y., Bergman, R.N., Bergmann, S., Biebermann, H., Blakemore, A.I.F., Boes, T., Bonnycastle, L.L., Bornstein, S.R., Brown, M.J., Buchanan, T.A., Busonero, F., Campbell, H., Cappuccio, F.P., Cavalcanti-Proença, C., Chen, Y.-D.I., Chen, C.-M., Chines, P.S., Clarke, R., Coin, L., Connell, J., Day, I.N.M., Heijer, M. den, Duan, J., Ebrahim, S., Elliott, P., Elosua, R., Eiriksdottir, G., Erdos, M.R., Eriksson, J.G., Facheris, M.F., Felix, S.B., Fischer-Posovszky, P., Folsom, A.R., Friedrich, N., Freimer, N.B., Fu, M., Gaget, S., Gejman, P. V, Geus, E.J.C., Gieger, C., Gjesing, A.P., Goel, A., Goyette, P., Grallert, H., Gräßler, J., Greenawalt, D.M., Groves, C.J., Gudnason, V., Guiducci, C., Hartikainen, A.-L., Hassanali, N., Hall, A.S., Havulinna, A.S., Hayward, C., Heath, A.C., Hengstenberg, C., Hicks, A.A., Hinney, A., Hofman, A., Homuth, G., Hui, J., Igl, W., Iribarren, C., Isomaa, B., Jacobs, K.B., Jarick, I., Jewell, E., John, U., Jørgensen, T., Jousilahti, P., Jula, A., Kaakinen, M., Kajantie, E., Kaplan, L.M., Kathiresan, S., Kettunen, J., Kinnunen, 
L., Knowles, J.W., Kolcic, I., König, I.R., Koskinen, S., Kovacs, P., Kuusisto, J., Kraft, P., Kvaløy, K., Laitinen, J., Lantieri, O., Lanzani, C., Launer, L.J., Lecoeur, C., Lehtimäki, T., Lettre, G., Liu, J., Lokki, M.-L., Lorentzon, M., Luben, R.N., Ludwig, B., Manunta, P., Marek, D., Marre, M., Martin, N.G., McArdle, W.L., McCarthy, A., McKnight, B., Meitinger, T., Melander, O., Meyre, D., Midthjell, K., Montgomery, G.W., Morken, M.A., Morris, A.P., Mulic, R., Ngwa, J.S., Nelis, M., Neville, M.J., Nyholt, D.R., O’Donnell, C.J., O’Rahilly, S., Ong, K.K., Oostra, B., Paré, G., Parker, A.N., Perola, M., Pichler, I., Pietiläinen, K.H., Platou, C.G.P., Polasek, O., Pouta, A., Rafelt, S., Raitakari, O., Rayner, N.W., Ridderstråle, M., Rief, W., Ruokonen, A., Robertson, N.R., Rzehak, P., Salomaa, V., Sanders, A.R., Sandhu, M.S., Sanna, S., Saramies, J., Savolainen, M.J., Scherag, S., Schipf, S., Schreiber, S., Schunkert, H., Silander, K., Sinisalo, J., Siscovick, D.S., Smit, J.H., Soranzo, N., Sovio, U., Stephens, J., Surakka, I., Swift, A.J., Tammesoo, M.-L., Tardif, J.-C., Teder-Laving, M., Teslovich, T.M., Thompson, J.R., Thomson, B., Tönjes, A., Tuomi, T., van Meurs, J.B.J., van Ommen, G.-J., Vatin, V., Viikari, J., Visvikis-Siest, S., Vitart, V., Vogel, C.I.G., Voight, B.F., Waite, L.L.,

Wallaschofski, H., Walters, G.B., Widen, E., Wiegand, S., Wild, S.H., Willemsen, G., Witte, D.R., Witteman, J.C., Xu, J., Zhang, Q., Zgaga, L., Ziegler, A., Zitting, P., Beilby, J.P., Farooqi, I.S., Hebebrand, J., Huikuri, H. V, James, A.L., Kähönen, M., Levinson, D.F., Macciardi, F., Nieminen, M.S., Ohlsson, C., Palmer, L.J., Ridker, P.M., Stumvoll, M., Beckmann, J.S., Boeing, H., Boerwinkle, E.,

Boomsma, D.I., Caulfield, M.J., Chanock, S.J., Collins, F.S., Cupples, L.A., Smith, G.D., Erdmann, J., Froguel, P., Grönberg, H., Gyllensten, U., Hall, P., Hansen, T., Harris, T.B., Hattersley, A.T., Hayes, R.B., Heinrich, J., Hu, F.B., Hveem, K., Illig, T., Jarvelin, M.-R., Kaprio, J., Karpe, F., Khaw, K.-T., Kiemeney, L.A., Krude, H., Laakso, M., Lawlor, D.A., Metspalu, A., Munroe, P.B., Ouwehand, W.H., Pedersen, O., Penninx, B.W., Peters, A., Pramstaller, P.P., Quertermous, T., Reinehr, T., Rissanen, A., Rudan, I., Samani, N.J., Schwarz, P.E.H., Shuldiner, A.R., Spector, T.D., Tuomilehto, J., Uda, M., Uitterlinden, A., Valle, T.T., Wabitsch, M., Waeber, G., Wareham, N.J., Watkins, H., Wilson, J.F., Wright, A.F., Zillikens, M.C., Chatterjee, N., McCarroll, S.A., Purcell, S., Schadt, E.E., Visscher, P.M., Assimes, T.L., Borecki, I.B., Deloukas, P., Fox, C.S., Groop, L.C., Haritunians, T., Hunter, D.J., Kaplan, R.C., Mohlke, K.L., O’Connell, J.R., Peltonen, L., Schlessinger, D., Strachan, D.P., van Duijn, C.M., Wichmann, H.-E., Frayling, T.M., Thorsteinsdottir, U., Abecasis, G.R., Barroso, I., Boehnke, M., Stefansson, K., North, K.E., I McCarthy, M., Hirschhorn, J.N., Ingelsson, E., Loos, R.J.F., 2010. Association analyses of 249,796 individuals reveal 18 new loci associated with body mass index. Nat. Genet. 42, 937-948. https://doi.org/10.1038/ng.686

van den Berg, A.E., Maas, J., Verheij, R. a., Groenewegen, P.P., 2010. Green space as a buffer between stressful life events and health. Soc. Sci. Med. 70, 1203-1210. https://doi.org/10.1016/j.socscimed.2010.01.002

VanderWeele, T.J., Vansteelandt, S., 2010. Odds ratios for mediation analysis for a dichotomous outcome. Am. J. Epidemiol. 172, 1339-1348. https://doi.org/10.1093/aje/kwq332

Visscher, T.L., Seidell, J.C., Molarius, a, van der Kuip, D., Hofman, a, Witteman, J.C., 2001. A comparison of body mass index, waist-hip ratio and waist circumference as predictors of all-cause mortality among the elderly: the Rotterdam study. Int. J. Obes. Relat. Metab. Disord. 25, 1730-1735. https://doi.org/10.1038/sj.ijo.0801787 
Wang, M., Beelen, R., Bellander, T., Birk, M., Cesaroni, G., Cirach, M., Cyrys, J., de Hoogh, K., Declercq, C., Dimakopoulou, K., Eeftens, M., Eriksen, K.T., Forastiere, F., Galassi, C., Grivas, G., Heinrich, J., Hoffmann, B., Ineichen, A., Korek, M., Lanki, T., Lindley, S., Modig, L., Mölter, A., Nafstad, P., Nieuwenhuijsen, M.J., Nystad, W., Olsson, D., Raaschou-Nielsen, O., Ragettli, M., Ranzi, A., Stempfelet, M., Sugiri, D., Tsai, M.-Y., Udvardy, O., Varró, M.J., Vienneau, D., Weinmayr, G., Wolf, K., Yli-Tuomi, T., Hoek, G., Brunekreef, B., 2014. Performance of multi-city land use regression models for nitrogen dioxide and fine particles. Environ. Health Perspect. 122, 843-9.

https://doi.org/10.1289/ehp.1307271

Ward Thompson, C., Aspinall, P., Roe, J., Robertson, L., Miller, D., 2016. Mitigating stress and supporting health in deprived urban communities: The importance of green space and the social environment. Int. J. Environ. Res. Public Health 13. https://doi.org/10.3390/ijerph13040440

Weier, J., Herring, D., 2000. Measuring Vegetation [WWW Document].

WHO Regional Office for Europe, 2016. Urban green spaces and health. Copenhaguen.

Witten, K., Hiscock, R., Pearce, J., Blakely, T., 2008. Neighbourhood access to open spaces and the physical activity of residents: A national study. Prev. Med. (Baltim). 47, 299-303. https://doi.org/10.1016/j.ypmed.2008.04.010

World Health Organization, 2008. Waist Circumference and Waist-Hip Ratio: Report of a WHO Expert Consultation. World Heal. Organ. 8-11. https://doi.org/10.1038/ejen.2009.139

World Health Organization, 1995. Physical status: the use and interpretation of anthropometry. Report of a WHO Expert Committee. Geneva, Switzerland.

Wormser, D., Kaptoge, S., Di Angelantonio, E., Wood, A.M., Pennells, L., Thompson, A., Sarwar, N., Kizer, J.R., Lawlor, D.A., Nordestgaard, B.G., Ridker, P., Salomaa, V., Stevens, J., Woodward, M., Sattar, N., Collins, R., Thompson, S.G., Whitlock, G., Danesh, J., 2011. Separate and combined associations of body-mass index and abdominal adiposity with cardiovascular disease: Collaborative analysis of 58 prospective studies. Lancet 377, 1085-1095. https://doi.org/10.1016/S01406736(11)60105-0 